\title{
Identification of emission indicators harmful compounds for assessment of dynamic state of a marine diesel engine
}

The operation of a ship's propulsion system is a variable process in time, which is described in both static and dynamic states. The mutual proportions between them depend primarily on a type of ship and tasks to which it was designed. In a case of special units of particular use (e.g. warships) and ships, which operate on narrow waters such as canals or port basins, participation of dynamic states is increasing significantly. Hence a necessity to analyze the dynamic states of marine diesel engines, among others in terms of their increased harmful compounds emission. The paper presents a methodology of engine dynamic state analysis, emission indicators that can be used to assess the dynamic state of a ship have been proposed. As an example of application, the analysis of harmful compounds emissions during dynamic states while a real cruise of navy ship has been carried out. It has been also proposed to use simple dynamics indicators such as single-base and chain indexes to describe the change in concentrations of harmful compounds in dynamic states.

Key words: dynamic states, emission, marine diesel engine

\section{Introduction}

The operation of a ship's propulsion system is a variable reaction in time, which is described in both static and dynamic states. The mutual proportions between them depend primarily on a type of ship and tasks to which it was designed. In the case of vessels carrying out passage between ports, dynamic states will account for a small share in an entire operational approach $[8,9,12]$. However, when we consider port areas and vessels operating in maneuvering a share of dynamic states of vessel is already a significant part of an operating time and should therefore be subject to separate considerations [6]. There are at least two reasons for this.

First of all, dynamic states are operating states of a marine diesel engine, forced by dynamic working conditions caused mainly by a changing moment of resistance [1]. This is when dynamic properties of processes occurring in marine diesel engines are clearly visible. An increasing load is accompanied by increasing dose of fuel, which clearly determines changes in a pollutant emission intensity. Emission intensity from an engine in its dynamic working states are strongly correlated with each other and depend primarily on a value of extortions that these states cause. The biggest extortion, both as to a value and a number of implemented extortions take place mainly in a port areas, which are close to human agglomerations, thus adversely affect on residents of these areas mainly healthily [5].

Secondly, with an additional converting mechanism, which should take into account, is a technical condition of an engine. During an implementation of a work process engine, its structure parameters change. It does not affect its performance, described by a set of output parameters. The relationship between structure parameters and output parameters of an engine allows, under certain conditions, to treat output parameters as symptoms of engine's technical condition, measured without dismantling it, because physicochemical processes occurring during working process and quantities describing them can generally be observed and measured from outside. These values include, among others, emission intensity of exhaust components [7].
The correct combustion process in an engine cylinder depends to a large extent on a properly operating intake system, which is ensure above all repeatability of a fuel injection process. Due to this repetition, it is not only important a beginning and end of injection, but also its course. The correctness of the first criteria (start and end of injection), in classic power systems, to a large extent, protects a high pressure fuel pump through such control parameters as: fuel dose and injection advance angle, which in first place should be treated as a basic parameter determining correctness of combustion process in diesel engines. In fact, even its slight deviations result in significant changes in a main engine performance indicators, including emission indicators[13].

Unless, as previously mentioned, the fuel pump corresponds to the beginning and the end of injection, the injector is responsible for its course, and more precisely parameters that describe its operation. The most important control parameter, determining a shape of injection, its correctness, and above all repeatability, is opening pressure of the injector. This parameter, compared to previously mentioned, undergoes the most frequent changes during exploatation of engine, and although its effect on combustion process is incomparably smaller than, for example, the angle of advance of fuel injection and it must be taken into account when analyzing combustion process. This parameter determines quality of fuel atomization, and thus preparation of a homogeneous combustible mixture in cylinder, which is particularly important in dynamic states forced by dynamic operating conditions. It is forced mainly by variable moment of resistance, when extortions regarding power supply are particularly important. The remaining parameter, on injector side, affecting injection process, concentrate on parameters describing geometric parameters of atomizer, which it is known, also undergoes changes during use. It could be a result of erosive fuel interaction for example.

Taking above into account, the analysis of engine dynamic states aimed primarily at their comparison, including their high variability, should focus on unambiguous determination of both the beginning and end of dynamic state and its course. In this case, it is desirable to use criteria that 
would help in the objective assessment of comparative concentration or emissions from dynamic states. The use of assessment indicators is one of commonly used methods in such cases.

\section{Evaluation indicators of dynamic states.}

Besides static states where emission level is relatively constant, dynamic states are also present. The nature of these changes depends on various extortions. These extortions can generally be divided into controllable ones, which are related to a way of controlling a ship and external extortion - dependent on atmospheric conditions.

The following relationship can be used to evaluate the dynamic state [13]:

$$
W_{i}=a_{i} \int_{0}^{t} C_{j, i}(t) d t
$$

where: $\mathrm{W}_{\mathrm{i}}$ - emission rating indicator, $\mathrm{C}_{\mathrm{j}, \mathrm{i}}(\mathrm{t})$ - concentration of any toxic compound at time $\mathrm{t}[\mathrm{ppm}], \mathrm{a}_{\mathrm{i}}-$ factor characteristic for a given compound $\mathrm{j}$ : $\mathrm{a}_{\mathrm{CO}}=0.000966, \mathrm{a}_{\mathrm{HC}}$ $=0.000478, \mathrm{a}_{\mathrm{NOx}}=0.001587, \mathrm{t}-$ time duration of transient state $[\mathrm{s}]$.

By integrating an area under a curve obtained from experiment or model, an integration curve is determined which describes a direction of changes in dynamic state. On the other hand, this indicator still does not describe a nature of changes. As is known from observation, depending on a value of extortion, a course of transient can significantly differ. These differences usually depend on an intensity course of individual phases in a transient state. Usually, two phases can be specified in course of a typical transient. The first one, characterized by the greatest dynamics of changes, which is accompanied by a sharp increase in harmful compounds concentration, as a rule, many exceeding the steady-state concentration. The second phase of transient state is characterized by a much less rapid course, it is monotonic in character and asymptotically approaches values of concentrations from steady states.

The following relationship can be used to identify the beginning and end of a dynamic state:

$$
\mathrm{S}_{\mathrm{i}}=\frac{\mathrm{dC}_{\mathrm{j}, \mathrm{i}}}{\mathrm{dt}}
$$

where: $S_{i}$ - indicator of the beginning and end of the dynamic state, $\mathrm{C}_{\mathrm{j}, \mathrm{i}}(\mathrm{t})$ - concentration of any toxic compound at time $\mathrm{t}[\mathrm{ppm}], \mathrm{t}-$ time duration of transient state $[\mathrm{s}]$.

In order to correctly identify dynamic states, analysis of concentration selected harmful compounds registered during a 30 minute cruise of navy ship was carried out. The concentration changes are shown in Fig. 1. The measurements were carried out using the portable TESTO 350 analyzer (Fig. 2). The analyzer data are presented in the Table 1.

The first step in analyzing recorded concentrations (Fig. 1) was identification of static and dynamic states. For this purpose, histograms were built that grouped concentration values of individual compounds in characteristic classes. A graphical example of this analysis is the histogram of nitrogen oxides concentration (Fig. 3).

To make a histogram it is necessary to determine size of data set (measurements), then determine data range and

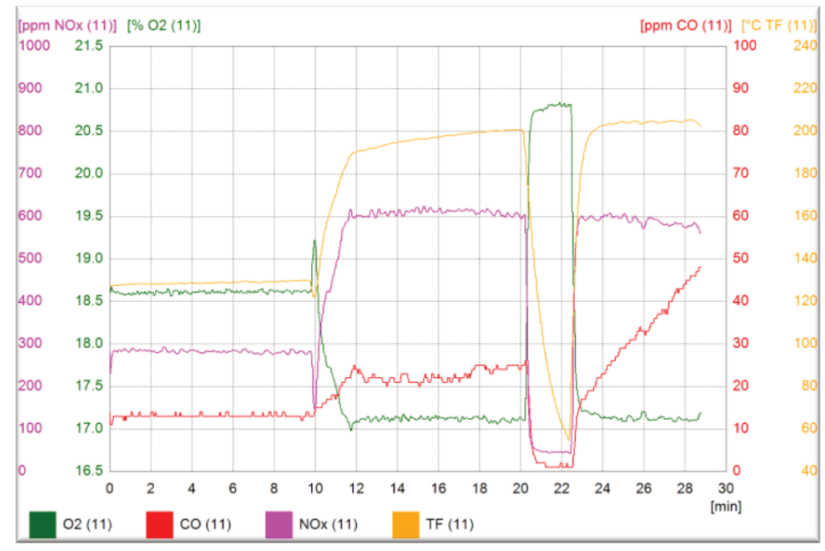

Fig. 1. Concentrations of harmful compounds during ship's operating

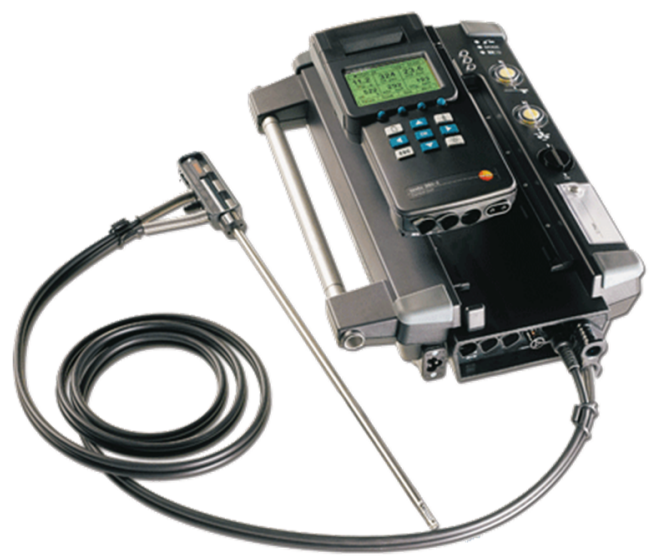

Fig. 2. Portable TESTO 350 analyzer [11]

\begin{tabular}{|c|c|c|}
\hline Parameter & Measuring range & Tolerance \\
\hline${ }^{\circ} \mathrm{C}$ (exhaust gas) & $\begin{array}{c}\text { from }-40 \\
\text { to }+1000^{\circ} \mathrm{C}\end{array}$ & $\max . \pm 5 \mathrm{~K}$ \\
\hline $\mathrm{O}_{2}$ & from 0 to $25 \%$ & \multirow{6}{*}{$\begin{array}{c}\text { According to MARPOL, } \\
\text { Annex VI or NOx } \\
\text { Technical Code }\end{array}$} \\
\hline $\mathrm{CO}$ & from 0 to $3000 \mathrm{ppm}$ & \\
\hline $\mathrm{NO}$ & from 0 to $3000 \mathrm{ppm}$ & \\
\hline $\mathrm{NO}_{2}$ & from 0 to $500 \mathrm{ppm}$ & \\
\hline $\mathrm{SO}_{2}$ & from 0 to $3000 \mathrm{ppm}$ & \\
\hline $\mathrm{CO}_{2}$ (IR) & from 0 to $40 \%$ & \\
\hline$P_{a b s}$ & $\begin{array}{l}\text { from } 600 \\
\text { to } 1150 \mathrm{hPa}\end{array}$ & $\begin{array}{c} \pm 5 \mathrm{hPa} \text { in } 22^{\circ} \mathrm{C} \\
\pm 10 \mathrm{hPa} \text { from }-5 \text { to } \\
+45^{\circ} \mathrm{C}\end{array}$ \\
\hline
\end{tabular}

Table 1. Parameters and measuring ranges of the TESTO 350 analyzer [11]

specify number of intervals. Due to the relatively large data set (registration time $30 \mathrm{~min}$, sampling frequency of the analyzer $1 \mathrm{~s}$ ), the so-called Smirnov pattern [4]:

$$
\mathrm{m}=1+3.322 \ln \mathrm{N}
$$

where: $\mathrm{m}$ - number of intervals (classes), $\mathrm{N}$ - number of observations (measurements).

Then width of compartment is determined according to relationship:

$$
\Delta \mathrm{x}=\frac{\mathrm{x}_{\max }-\mathrm{x}_{\min }}{\mathrm{m}}
$$

where: $x_{\min }-$ minimum value of data, $x_{\max }-$ maximum value of data, $\mathrm{m}$-number of intervals. 
Let $\chi_{\mathrm{i}}$ represents the output data variable $\mathrm{x}$ then:

$$
\chi_{\mathrm{i}}=\mathrm{x}_{\min }+0.5 \cdot \Delta \mathrm{x}+\mathrm{i} \cdot \Delta \mathrm{x}
$$

for $\mathrm{i}=0,1, \ldots, \mathrm{m}-1$.

Defining i-th interval, which is to be a range of values from to, but is not including:

$$
\Delta_{i} \in\left(\chi_{i}-0.5 \cdot \Delta x, \chi_{i}+0.5 \cdot \Delta x,\right)
$$

for $\mathrm{i}=0,1, \ldots, \mathrm{m}-1$.

The function defined will have the form:

$$
y_{i}(x)=\left\{\begin{array}{cc}
1, & \text { when } x \in \Delta_{i} \\
0, & \text { elsewhere }
\end{array}\right.
$$

Finally, the histogram sequence is evaluated: for $\mathrm{i}=0$, $1, \ldots, \mathrm{m}-1$

$$
\mathrm{h}_{\mathrm{i}}=\sum_{\mathrm{j}=0}^{\mathrm{n}-1} \mathrm{y}_{\mathrm{i}}\left(\mathrm{x}_{\mathrm{j}}\right)
$$

where: $\mathrm{n}$ - number of input elements of the histogram.

The histogram analysis of nitrogen oxide concentrations shows that during the cruise there were three static states in which concentrations reached the following values: $0-50$ ppm, 250-300 ppm and 550-600 ppm. The ship lasted the longest in a state where it reached 550-600 ppm, while the shortest was in the state in which concentrations reached value of up to $50 \mathrm{ppm}$. During this time, main engine of the ship was running idle. Other histogram values are assumed as dynamic states (Fig. 3).

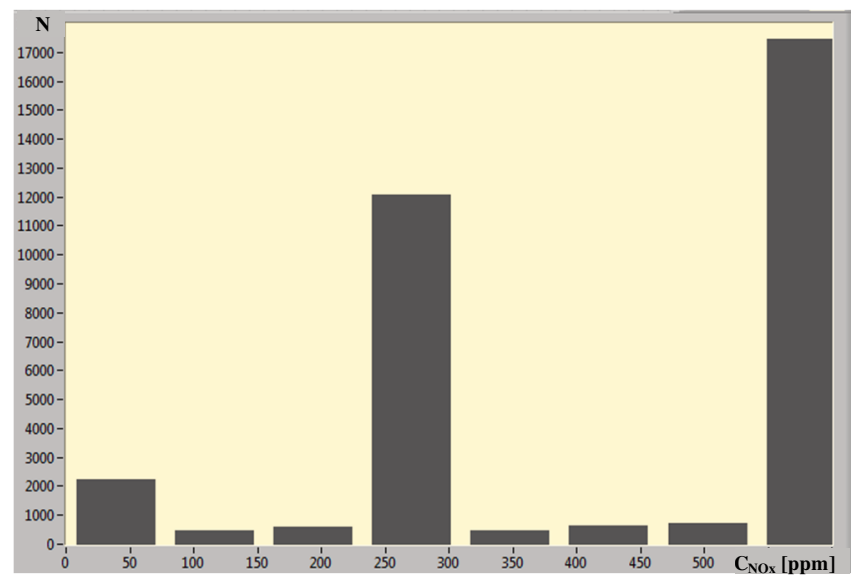

Fig. 3. Histogram of nitrogen oxide concentrations in static states

In order to carry out a correct concentration analysis of harmful compounds during dynamic states, it is necessary to perform filtration of individual time transitions and subject them to further processing eliminating accidental errors and errors related to measurements. For this purpose, a lowpass Butterworth filter has been used. This filter, in relation to other filters, is characterized by the fact that it has a flat course of the amplitude characteristic in a bandwidth. Dynamic state analysis was performed based on the LabVIEW development environment [2].

Figure 4 shows course of nitrogen oxides concentration after filtration.

By identifying the beginning and end of dynamic state, nitrogen oxides concentration in time course was differentiated to obtain waveform shown in Figure 5.

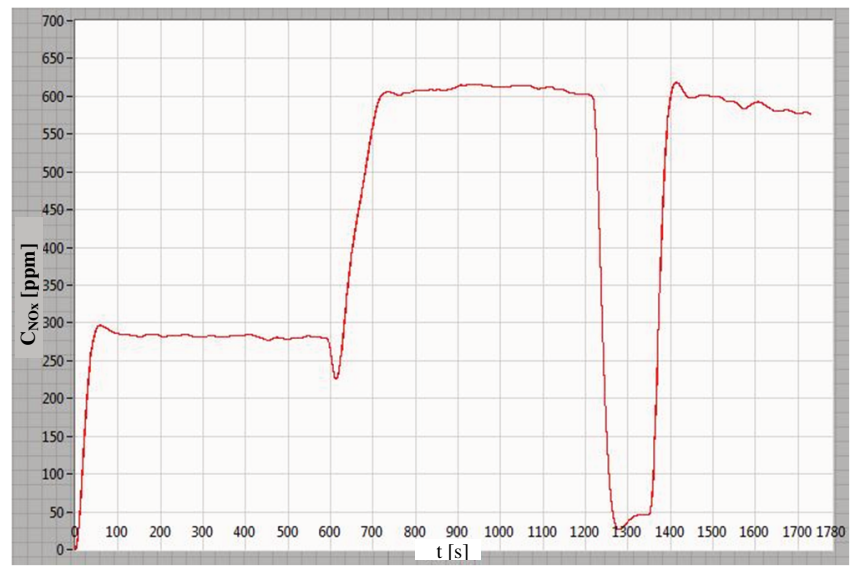

Fig. 4. Filtered course of nitrogen oxides concentration

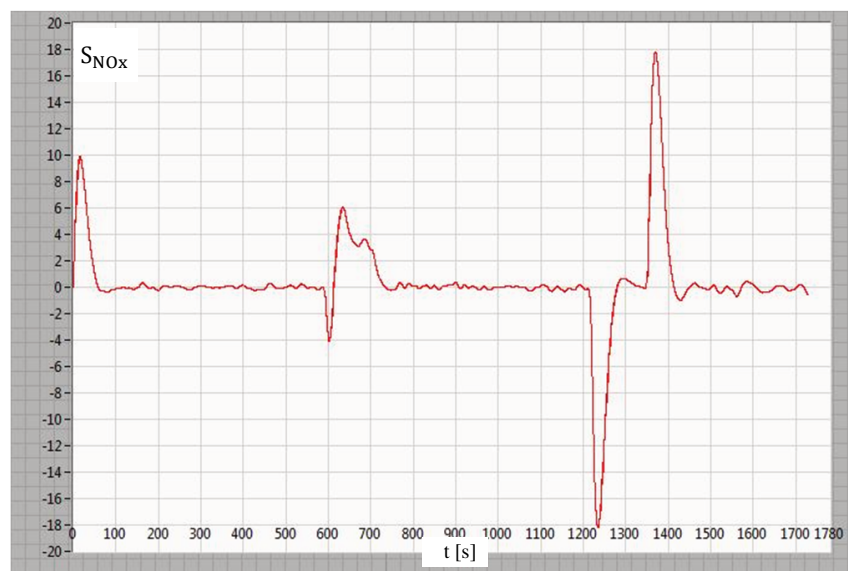

Fig. 5. Derivative course of nitrogen oxides concentration

Figure 6 shows integrated time course of nitrogen oxi-des concentration. In order to carry out a more thorough analysis, integrating defined ranges of transient states should be performed, however, according to goal set by authors, determine the beginning, end and direction of changes in dynamic state, course of obtained curve is sufficient.

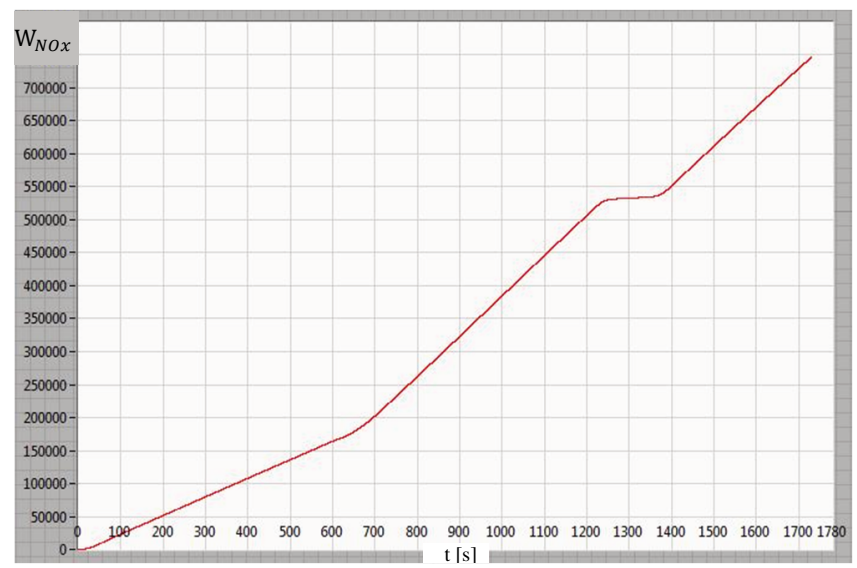

Fig. 6. The integrated course of nitrogen oxides concentration

From presented runs, it is possible to define time intervals in which dynamic states occurred during ship's cruise. In first minutes of the cruise there is a transitory state which will not be taken into consideration due to the lack of initial data. The values of differentials show speed of changes in 
harmful compounds emission. They also show direction of changes in dynamic state. The obtained data presented, at time $t=600 \mathrm{~s}$ acceleration of the ship, which ended after time $t=200 \mathrm{~s}$. Subsequent changes in the ship's movement occurred between $t_{p}=1200 \mathrm{~s} \mathrm{i} t_{k}=1300 \mathrm{~s}$. At that time, the ship stopped, then accelerated (from $t_{p}=1350 \mathrm{~s}$ to $t_{k}=$ $1450 \mathrm{~s}$ ) and then carried out next stages of ship's task.

In Figure 7, integrated and differentiated waveforms were placed with indication of dynamic states during the cruise of navy ship.

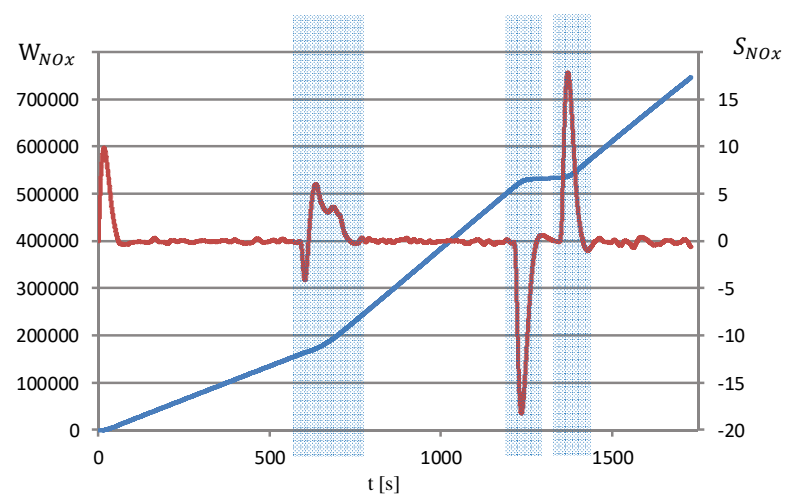

Fig. 7. Dynamic changes in the concentration of nitrogen oxides

Simple dynamics indicators may be used to describe dynamics of harmful compounds concentrations in which a given time series can be analyzed. These include singlebase and string indexes. These indexes are widely used, for example in econometrics, but can be successfully used and in other applications.

Dynamics indexes are defined as follows [10]:

$$
\mathrm{I}=\frac{\mathrm{x}_{\mathrm{n}}}{\mathrm{x}_{0}} \text { or } \mathrm{I}=\frac{\mathrm{x}_{\mathrm{n}}}{\mathrm{x}_{0}} \cdot 100 \%
$$

where: $x_{n}-a$ level of phenomenon during tested period, $x_{0}$ - a level of phenomenon during reference period.

These indexes are characterized by the following properties:

- indexes are non-negative numbers $(i \geq 0)$,

- indexes are non-dimensional numbers,

- if a level of phenomenon is equal, they are equal to one $\left(\mathrm{x}_{\mathrm{n}}=\mathrm{x}_{0}\right)$,

- in the case of reducing a value by $100 \%$, we get information about percentage of level of phenomenon in n-th period being higher or lower than in an initial period.

Analyzing a given time series of harmful compounds concentrations in a form $\mathrm{C}_{\mathrm{j}, 1}, \mathrm{C}_{\mathrm{j}, 2}, \ldots, \mathrm{C}_{\mathrm{j}, \mathrm{n}}$ could be used single-base index or chain index strings.

The one-base indexes represent changes that occurred in level of phenomenon in subsequent periods in relation to period assumed as basic (base time). With regard to analysis of harmful compounds concentrations, single-base index is as follows [10]:

$$
I_{n / 0}=\frac{C_{j, n}}{C_{j, 0}} \cdot 100 \%
$$

where: $\mathrm{C}_{\mathrm{j}, \mathrm{n}}$ - harmful compound concentration during tested period, $\mathrm{C}_{\mathrm{j}, 0}-$ harmful compound concentration during reference period.
Chain indexes inform what changes occurred in period considered in relation to previous period. For analysis of harmful compounds concentrations, chain index is as follows [10]:

$$
I_{n / n-1}=\frac{C_{j, n}}{C_{j, n-1}} \cdot 100 \%
$$

where: $\mathrm{C}_{\mathrm{j}, \mathrm{n}}$ - harmful compound concentration during tested period, $\mathrm{C}_{\mathrm{j}, \mathrm{n}-1}-$ harmful compound concentration in previous period.

Figures 8-10 present changes in nitrogen oxides and carbon dioxide concentration during dynamic states. Onebase indexes were used for analysis, while relative values of dynamics index were left. The first state refers to the time interval from $t_{p}=500 \mathrm{~s}$ do $t_{k}=800 \mathrm{~s}$ cruise mode depicted in Fig. 2. During this time the ship carried out a maneuver of increasing velocity. The presented characteristics in Fig. 8 show that during maneuver, a course of changing nitrogen oxide index is larger than the carbon dioxide index. The concentration of nitrogen oxides index has more than doubled and the carbon dioxide index more than 1.5 times compared to initial state. This may indicate that during the maneuver, thermal load of engine increased due to increase of fuel dose, whereas carbon dioxide concentration (which is closely related to fuel consumption) gently stabilized at set level.

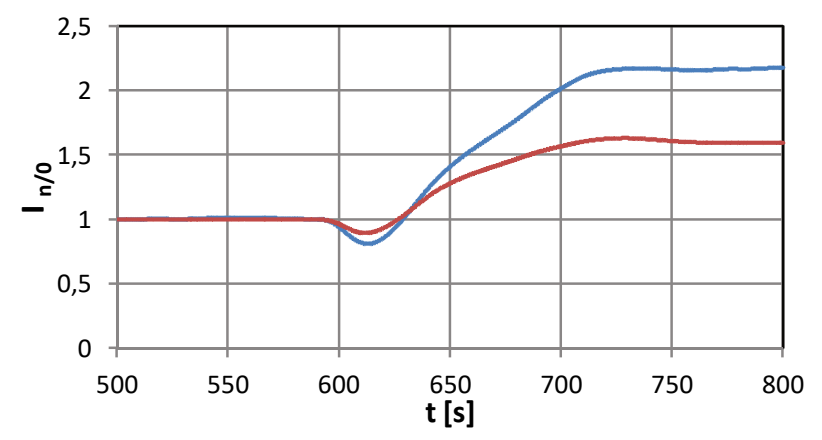

Fig. 8. One-base indexes of nitrogen oxides and carbon dioxide concentrations during acceleration maneuver. Blue line $-I_{n / 0 ~ N O x}$, red line $-I_{n / 0 ~ C O 2}$

Figure 9 shows maneuver reducing velocity of the ship. This maneuver was carried out from $t_{p}=1150 \mathrm{~s}$ to $t_{k}=1350 \mathrm{~s}$. The indexes of both concentrations overlap in entire analyzed range and set at a new level at the end of maneuver.

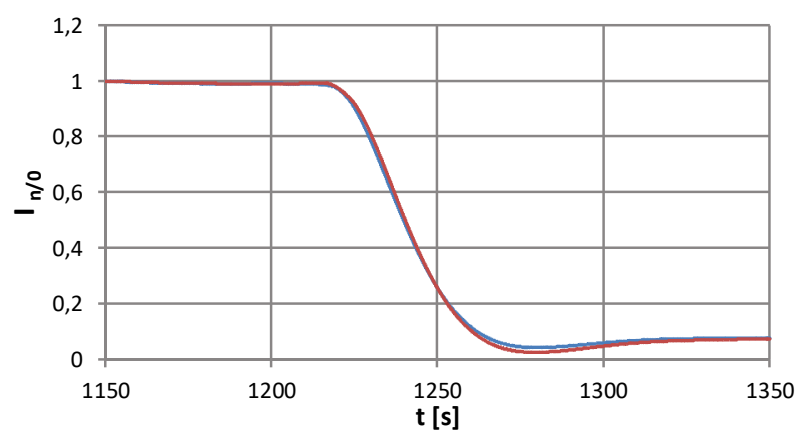

Fig. 9. One-base indexes nitrogen oxides and carbon dioxide concentrations during slowing down velocity. Blue line $-\mathrm{I}_{\mathrm{n} / 0 \mathrm{NOx}}$, red line $-\mathrm{I}_{\mathrm{n} / 0 \mathrm{CO} 2}$ 


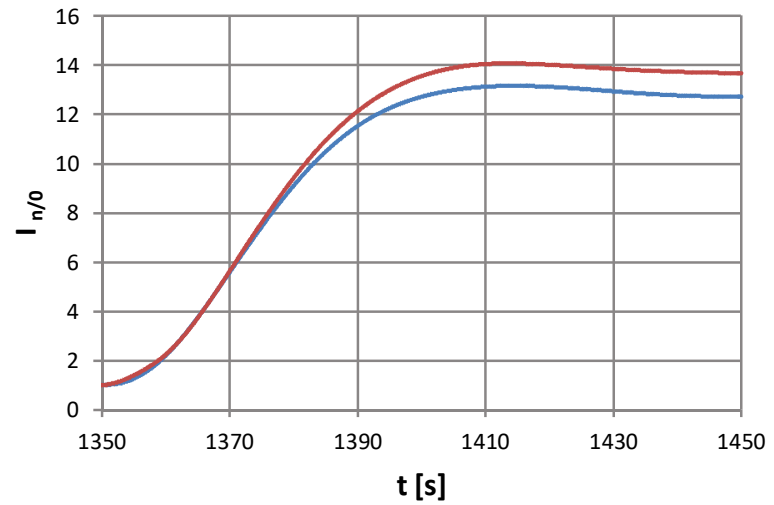

Fig. 10. One-base indexes of nitrogen oxides and carbon dioxide concentrations during acceleration maneuver from a place. Blue line $-I_{n / 0}$ NOx , red line $-\mathrm{I}_{\mathrm{n} / 0 \mathrm{CO} 2}$

The last maneuver during ship's cruise was acceleration from a place. This maneuver took place from $t_{p}=1350 \mathrm{~s}$ to $t_{k}=1450 \mathrm{~s}$. In the first phase of maneuver to time $\mathrm{t}=1370 \mathrm{~s}$ indexes overlap and then there were discrepancies. The curve of nitrogen oxides index is lower than carbon dioxide index (Fig. 10). In comparison with acceleration realized in time from $t_{p}=500 s$ do $t_{k}=800 \mathrm{~s}$, this maneuver is characterized by a much more rapid course. The carbon dioxide concentration index was even fourteen times higher than initial value, while the nitrogen oxide index increased thirteen times compared to entry value of maneuver. In general, it is assumed an increase in concentration indexes in this range from eleven to fourteen times greater than initial value.

\section{Summary}

The paper presents the methodology for identification of dynamic states of toxic compounds concentrations. The use of simple indexes of dynamics as a tool that can describe time courses during transient processes of a marine diesel engine gives great possibilities of identification and then analysis of dynamic states. The application of chain indexes to describe changes in dynamic states emissions is only presented in the paper. Future studies should also include the analysis of measurement data using these indexes.

Due to the important role of extortion values as well as dynamics of their changes in future research, it would also be necessary to consider dynamic states related to changing an engine load and perform a comparative analysis with harmful compounds emission in synchronized time intervals of measuring instruments (e.g. sensor connected to the load indicator of governor with a device for measuring harmful compounds emissions). The obtained data should be subjected to filtration process and then, using tools presented in the paper, carry out a comparative analysis of harmful compounds concentration together with recorded load characteristics.

Further analysis of dynamic states should be focused on:

- carry out searching for indicators of engine's dynamic states, e.g. determining intensity of dynamic states by studying a slant of distributions,

- using neural networks to more accurately analyze dynamic states,

- conducting tests for typical ship engine damage and more accurate analysis of time courses using presented description methods.

\section{Bibliography}

[1] CARLTON, J. Marine Propellers and Propulsion. MPG Books Ltd.

[2] CHRUŚCIEL, M. Labview w praktyce. Wydawnictwo BTC. Legionowo 2008.

[3] GATNAR, E. Podejście wielomodelowe w zagadnieniach dyskryminacji i regresji. Wydawnictwo PWM. Warszawa 2008.

[4] GATNAR, E., WALESIAK, M. Statystyczna analiza danych $\mathrm{z}$ wykorzystaniem programu R. Wydawnictwo PWM. Warszawa 2008.

[5] KNIAZIEWICZ, T. Modelowanie procesów emisji spalin okrętowych tłokowych silników spalinowych napędu głównego w rzeczywistych warunkach eksploatacji. Zeszyty Naukowe AMW. Gdynia 2013.

[6] MARIN, Sea shipping emission 2014. Final report. Bilthoven Netherlands 2016.

[7] MERKISZ, J., PIASECZNY, L., KNIAZIEWICZ, T. Zagadnienia emisji spalin silników okrętowych. Wydawnictwo Politechniki Poznańskiej. Poznań 2016.

Ryszard Zadrąg, DEng. - Faculty of Mechanical and Electrical Engineering, Polish Naval Academy. e-mail: r.zadrag@amw.gdynia.pl

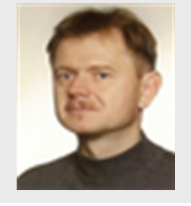

[8] PIASECZNY, L. Metody wyznaczania statycznych i dynamicznych charakterystyk emisji związków toksycznych z silników spalinowych statków morskich. Sprawozdanie z projektu badawczego N509 572 839. AMW Gdynia 2013.

[9] SCHULTEN, P. The interaction between diesel engines, ship and propellers during manoeuvring. DUP science is an imprint of Delft University Press. Delft 2005.

[10] STARZYNSKA, W. Statystyka praktyczna. Wydawnictwo PWM. Warszawa 2012.

[11] TESTO 350 MARITIME, Instruction manual. Lenzkirch 2010.

[12] WOJNOWSKI, W. Okrętowe siłownie spalinowe. $A M W$. Gdynia 1998.

[13] ZADRĄG, R., ZELLMA, M. Modelowanie emisji związków toksycznych okrętowego silnika spalinowego podczas stanów nieustalonych przy zmiennym kącie wyprzedzenia wtrysku paliwa. Journal of Polish Cimac. 2014, 8(1). Artur Bogdanowicz, MEng. - Faculty of Mechanical
and Electrical Engineering, Polish Naval Academy.
e-mail: a.bogdanowicz@amw.gdynia.pl 